\title{
無機系接着剂のディスク型シヤキーへの適用性 \\ ADAPTABILITY OF CEMENT-BASED ADHESIVE TO DISK TYPE SHEAR-KEY
}

\author{
阿部隆英*1, 高瀬 裕 也*2, 安藤 重 裕 $^{* 3}$, \\ 坂本啓太 ${ }^{* 4}$, 田村 努*5, 兼吉孝征*6 \\ Takahide ABE, Yuya TAKASE, Sigehiro ANDO, \\ Keita SAKAMOTO, Tsutomu TAMURA and Takayuki KANEYOSHI
}

\begin{abstract}
In the structure joints, disk-type shear keys are used to connect retrofitting members to existing members, and they are strengthened by applying an epoxy adhesive. The authors investigated the adaptability of a cement-based adhesive to disk-type shear keys by conducting tests and by a two-dimensional FEM analysis. As a result of experimental tests, the bond strength of the cement-based adhesive was lower. Moreover, the vertical displacement of the anchor bolt was larger in the analysis. However, the maximum shear forces exceeded the calculated values for most specimens. Finally, it was concluded that a cement-based adhesive was able to be applied.
\end{abstract}

Keywords: Seismic retrofitting, Adhesives, Cement-based Adhesive, Joint, Disk type shear-key 耐震補強，接着剤，無機系接着剂，接合部，ディスク型シヤキー

\section{1. はじめに}

旧耐震規準で設計された既存建築物の耐震補強 ${ }^{11}$ は，規模の大き な地震が多く発生するわが国において, 極めて重要な課題である。 一般的な耐震補強では, 既存躯体と補強部材の接合にあと施工アン カーやディスク型シヤキー ${ }^{21,33}$ が使用され，これらを既存コンクリー トに定着するために接着剤が用いられる。接着剤の成分として, 基 本的には有機系のものが多く採用されているが，2010 年の各種合成 構造設計指針 ${ }^{4)}$ の改定により, 制約はあるものの無機系接着剤の使 用が認められ，近年，この研究開発例衤将5) が広く行われている。無機 系接着剂には揮発性の有機化合物が使用されていないことや, 長期 荷重が作用寸る部位への適用性から，普及一の期待が高まっている。 無機系接着剤を対象としたあと施工アンカーの付着実験は多く行わ れているが，せん断実験について検証された研究例は著者らが知る 限り少なく, 付着特性の違いが力学性能に及ぼす影響については未 解明に近い。そこで本研究では，あと施エアンカーよりも高いせん 断耐力を発揮するディスク型シヤキーを対象に，有機系と無機系の 接着剂をそれぞれ用いた場合のせん断抵抗性能を検証する。

Fig.1 にディスク型シヤキーの概念図を示す。ディスク型シヤキー は, ディスク (Steel disk), アンカーボルト (Anchor bolt), 高ナット (Nut) および接続ボルト (Connecting bolt) から構成され, ディスクと アンカーボルトが注入型の接着剤によって既存コンクリートに定着 される。ここでアンカーボルトの定着について, Fig.1に示寸通りボ ルトの先端に芯棒打ち込み式の金属拡張部 (以下, 拡張部と記述する) を有している。しかしこの拡張部は，施工時の仮固定のために用い られているものであり, アンカーボルトの穿孔径は, 接着系アンカー

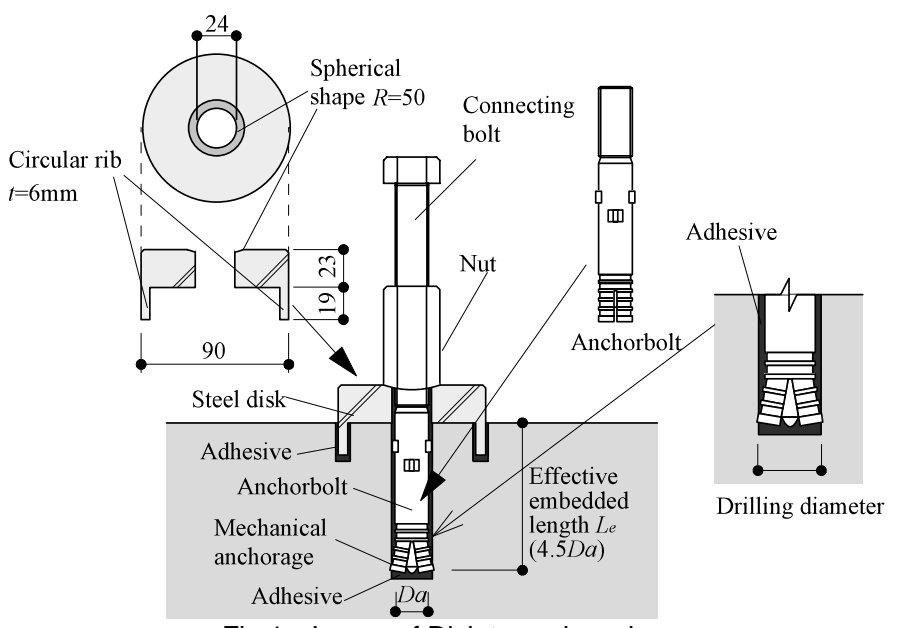

Fig.1 Image of Disk type shear-key

用の広めのサイズ（径 $20 \mathrm{~mm}$ のボルトに対し，穿孔径 $24 \mathrm{~mm} ）$ が採 用されている。したがって, この拡張部が有する構造的な抵抗性能 は非常に小さく, 基本的には接着剤の付着によって, アンカーボル トがコンクリートに定着される ${ }^{2)}$

そこで本論文では，はじめに両接着剤の付着特性を把握するため の付着実験を行う。次いで正負交番繰り返し加力を与えるせん断載 荷実験を実施し, 接着剤の違いがせん断抵抗性能に与える影響につ いて検証する。続いて, 付着実験の両接着剤の付着特性をモデル化 して，これを用いた 2 次元有限要素解析を行い，せん断載荷実験の 再現性について検証するとともに，接着剤の付着特性がせん断抵抗 性能に及ぼす影響について考察することで, 無機系接着剤のディス
*1 飛島建設耐震ソリューション部 主任

*2 室蘭工業大学大学院工学研究科くらし環境系領域 准教授・博士 (工学)

*3 住友大阪セメントセメント・コンクリート研究所 課長・博士 (工学)

*4 飛島建設耐震ソリューション部 主任・修士(工学)

*5 住友大阪セメントセメント・コンクリート研究所 係長

*6 住友大阪セメント建材部 課長
Chief, Seismic solution department, TOBISHIMA Corporation

Assoc. Prof., College of Environmental Technology, Muroran Institute of Technology, Ph.D.

Manager, Concrete research laboratory, SUMITOMO OSAKA CEMENT Co., Ltd., Dr.Eng.

Chief, Seismic solution department, TOBISHIMA Corporation, M.Eng.

Subsection chief, Concrete research laboratory, SUMITOMO OSAKA CEMENT Co., Ltd.

Manager, Cement-related products division, SUMITOMO OSAKA CEMENT Co., Ltd. 
ク型シヤキーへの適用性について検討する。なお本論文では，有機 系接着剂と無機系接着剤の硬化後に得られる力学的な付着特性に着 眼する。

\section{2. 本実験の概要}

本論文では付着実験とせん断載荷実験の 2 タイプの実験を実施す る。本論文で用いる接着剤について，有機系は広く市販されている エポキシ系接着剤であり，無機系については既往の文献 ${ }^{5)}$ で用いら れているものをベースとし，流動性が高くなるように，成分を一部 変更したものである。以下に，両実験の概要をそれぞれ記述する。

\section{1 接着剂の付着特性を把握するための付着実験}

\section{1 .1 試験体パラメータ}

Table1 に試験体パラメータを示す。Table2 およびTable3 に，アン カー筋の機械的性質とコンクリートの材料特性をそれぞれ示す。本 実験では全 9 パラメータの試験体の載荷実験を行う。試験体パラメー 夕は，1) 接着剤の種類，2) アンカー筋の種類，3) コンクリート圧縮 強度 $\sigma_{\mathrm{B}}$ である。アンカー筋の種類としては, 全ネジボルトと丸鋼の 2 種類を対象とする。全ネジボルトを用いた理由は，本実験で用い る無機系接着剤の一般的な付着特性を把握するためである。またディ スク型シヤキーで用いられるアンカーボルトやディスクは，異形鉄 筋と異なり，丸鋼のような滑らかな表面を持つことから，このよう な界面での付着特性を把握するために丸鋼を用いる。アンカー筋の 降伏で最大引抜き荷重が決まらないよう, アンカー筋には高強度の 素材を用いることとし，全ネジボルトはSNB-7, 丸鋼は S45C とする。 アンカーボルト径 $\phi$ は, 本論文で扱うディスク型シヤキーと同じ,

Table 1 Specimen parameters for pull-out test

\begin{tabular}{|c|c|c|c|c|}
\hline $\begin{array}{c}\text { Specimen } \\
\text { name }\end{array}$ & Adhesive & $\begin{array}{c}\text { Anchor - } \\
\text { borlt }\end{array}$ & $\begin{array}{c}F_{C} \\
\left(\mathrm{~N} / \mathrm{mm}^{2}\right)\end{array}$ & $\begin{array}{c}L_{\text {eavg }} \\
(\mathrm{mm})\end{array}$ \\
\hline BC09-M 20 & \multirow{3}{*}{ Cement- based } & \multirow{3}{*}{ M 20} & 9 & 101.8 \\
\hline BC18-M 20 & & & 18 & 101.8 \\
\hline BC $30-M 20$ & & & 30 & 101.1 \\
\hline BE09- $\phi 20$ & \multirow{3}{*}{ Epoxy } & \multirow{6}{*}{$\phi 20$} & 9 & 91.74 \\
\hline BE $18-\phi 20$ & & & 18 & 91.85 \\
\hline BE30- $\phi 20$ & & & 30 & 90.76 \\
\hline BC09- $\phi 20$ & \multirow{3}{*}{ Cement- based } & & 9 & 90.47 \\
\hline BC $18-\phi 20$ & & & 18 & 90.88 \\
\hline$B C 30-\phi 20$ & & & 30 & 90.62 \\
\hline
\end{tabular}

$F_{C}$ : Design compressive strength of concrete, $L_{\text {eavg }}$ : M esured average embedded length of anchor bolt

Table 2 Material properties of concrete for pull-out test

\begin{tabular}{ccc}
\hline $\begin{array}{c}F_{C} \\
\left(\mathrm{~N} / \mathrm{mm}^{2}\right)\end{array}$ & $\begin{array}{c}\sigma_{B} \\
\left(\mathrm{~N} / \mathrm{mm}^{2}\right)\end{array}$ & $\begin{array}{c}E_{c} \\
\left(\mathrm{kN} / \mathrm{mm}^{2}\right)\end{array}$ \\
\hline 9 & 8.34 & 13.4 \\
\hline 18 & 21.6 & 26.4 \\
\hline 30 & 30.7 & 29.0 \\
\hline
\end{tabular}

$\sigma_{B}$ : Concrete compressive strength, $E_{c}$ : $Y$ oung's modulus

Table 3 Material properties of anchor bolts

\begin{tabular}{ccccc}
\hline $\begin{array}{c}\text { A nchor - } \\
\text { bolt }\end{array}$ & $\begin{array}{c}\sigma_{y} \\
\left(\mathrm{~N} / \mathrm{mm}^{2}\right)\end{array}$ & $\begin{array}{c}\sigma_{u} \\
\left(\mathrm{~N} / \mathrm{mm}^{2}\right)\end{array}$ & $\begin{array}{c}E_{s} \\
\left(\mathrm{kN} / \mathrm{mm}^{2}\right)\end{array}$ & $\begin{array}{c}\delta \\
(\%)\end{array}$ \\
\hline M 20 & 726 & 965 & 178 & 6.04 \\
\hline$\phi 20$ & 607 & 771 & 204 & 10.9
\end{tabular}

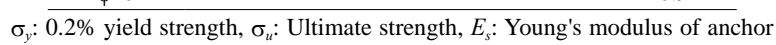
bolt, $\delta$ : Elongation after fracture $\phi=20 \mathrm{~mm}$ とする。 $\sigma_{\mathrm{B}}$ については一般的な耐震補強を想定して, 目標 強度を 10 30N/ $\mathrm{mm}^{2}$ とし, $F_{\mathrm{C}}=9,18,30 \mathrm{~N} / \mathrm{mm}^{2}$ とする。アンカー筋 の有効埋め込み深さは，全ネジボルトを用いる試験体で $5 \phi ， 丸$ 鋼を 用いる試験体ではディスク型シヤキーと同じ $4.5 \phi$ とすることで， ア ンカー筋の降伏前に，付着破壊するように配慮する。

\section{1 .2 試験体形状}

Fig.2 に付着実験で用いる試験体の諸元寸法を示す。付着実験では, $1700 \times 800 \times 400 \mathrm{~mm}$ の無筋コンクリートブロックの試験体を用い, その上面に, 試験体パラメータに則して $160 \mathrm{~mm}$ 間隔でアンカー筋を 定着する。各パラメータで 5 本づつ試験体を用意する。

\section{1 .3 載荷方法および計測方法}

Fig.3 に加力装置図と計測方法を示す。コンクリートのコーン状破 壊を防ぐため, Fig.3 に示寸反力板 (Reaction plate) をアンカー筋の 周囲に設置する。反力板の上に, 溝型鋼を組み合わせて加力フレー ムを構成し, アンカー筋の頂部にセンターホールジャッキを設置し, このジャッキにより引抜荷重 $T$ を与える。載荷履歴は単調載荷とす る。アンカー筋のコンクリート表面から $20 \mathrm{~mm}$ の位置に計測用のプ レートを取り付け，このコンクリート表面からの浮き上がりを左右 2 点計測して, これらの平均值を引抜変位とする。

\section{2 接着剂を違えたディスク型シャキーのせん断載荷実験}

\section{2 .1 試験体パラメータ}

Table4 に試験体パラメータを示す。せん断載荷実験のパラメータ は，接着剤の種類およびコンクリート圧縮強度 $\sigma_{\mathrm{B}}$ である。接着剤の 種類は付着実験と同様に有機系と無機系の 2 タイプ， $\sigma_{\mathrm{B}}$ については 付着実験と同様に 3 種類とした計 6 体の載荷実験を行う。アンカー ボルトの有効埋め込み深さは全て 4.5 Da（Da はアンカーボルトの軸 部径)である。また $F_{\mathrm{C}}=9,18 \mathrm{~N} / \mathrm{mm}^{2}$ とした試験体では, 軸応力 $\sigma_{\mathrm{N}} を 0.5$

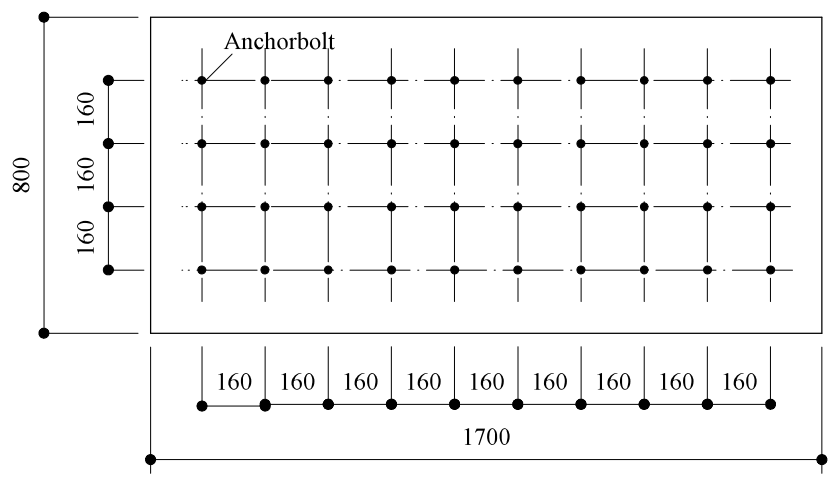

Fig.2 Test specimen for pull-out test

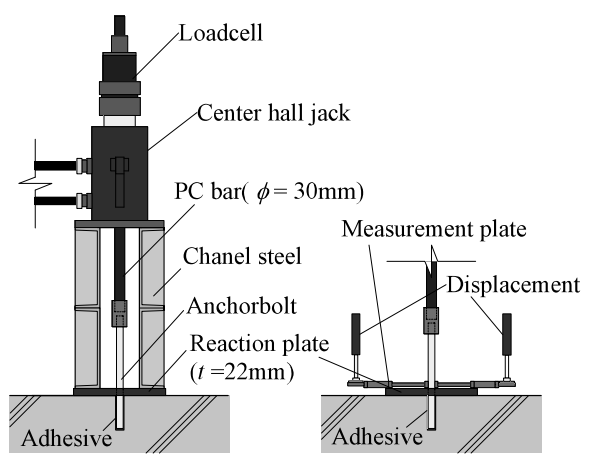

Fig.3 Loading set-up and measurement of pull-out test 
$\mathrm{N} / \mathrm{mm}^{2}, F_{\mathrm{C}}=30 \mathrm{~N} / \mathrm{mm}^{2}$ では $\sigma_{\mathrm{N}}=0.75 \mathrm{~N} / \mathrm{mm}^{2}$ とし, 軸力として, $\sigma_{\mathrm{N}}$ に接 合面の面積 $(540 \mathrm{~mm} \times 200 \mathrm{~mm})$ を乗じた值を与える。

\section{2 .2 試験体形状}

Fig.4 に試験体の諸元寸法を, Table5 にグラウトおよび無機系接着 剂の材料特性を示す。本試験体は, 而震補強部材を既存架構の内側 に取り付ける，いわゆる「内付け耐震補強」の既存躯体から接合部 までの一部を模擬したものである。既存躯体に相当するコンクリー 卜部分は，幅 $400 \mathrm{~mm}$ ，長さ $580 \mathrm{~mm}$ ，高さ $200 \mathrm{~mm}$ である。接合部に 相当する増設側は，幅 $200 \mathrm{~mm}$ ，長さ $540 \mathrm{~mm}$ ，高さ $200 \mathrm{~mm}$ である。 コンクリート部分にディスク型シヤキーを定着した後に，接合面に

Table 4 Specimen list for shear loading test

\begin{tabular}{|c|c|c|c|c|}
\hline $\begin{array}{c}\text { Spesimen } \\
\text { name }\end{array}$ & Adhesive & $\begin{array}{c}\sigma_{B} \\
\left(\mathrm{~N} / \mathrm{mm}^{2}\right)\end{array}$ & $\begin{array}{c}E_{s} \\
\left(\mathrm{kN} / \mathrm{mm}^{2}\right)\end{array}$ & $\begin{array}{c}\sigma_{t} \\
\left(\mathrm{~N} / \mathrm{mm}^{2}\right)\end{array}$ \\
\hline E09-50 & Epoxy & \multirow{2}{*}{11.1} & \multirow{2}{*}{15.5} & \multirow{2}{*}{1.03} \\
\hline C09-50 & Cement-based & & & \\
\hline E18-50 & Epoxy & \multirow{2}{*}{15.2} & \multirow{2}{*}{22.3} & \multirow{2}{*}{1.71} \\
\hline C18-50 & Cement-based & & & \\
\hline E30-75 & Epoxy & \multirow{2}{*}{34.8} & \multirow{2}{*}{30.7} & \multirow{2}{*}{2.76} \\
\hline C $30-75$ & Cement-based & & & \\
\hline
\end{tabular}

$\sigma_{B}$ : Concrete compressive strength, $E_{c}:$ Y oung's modulus of concrete, $\sigma_{t}:$ Concrete split strength

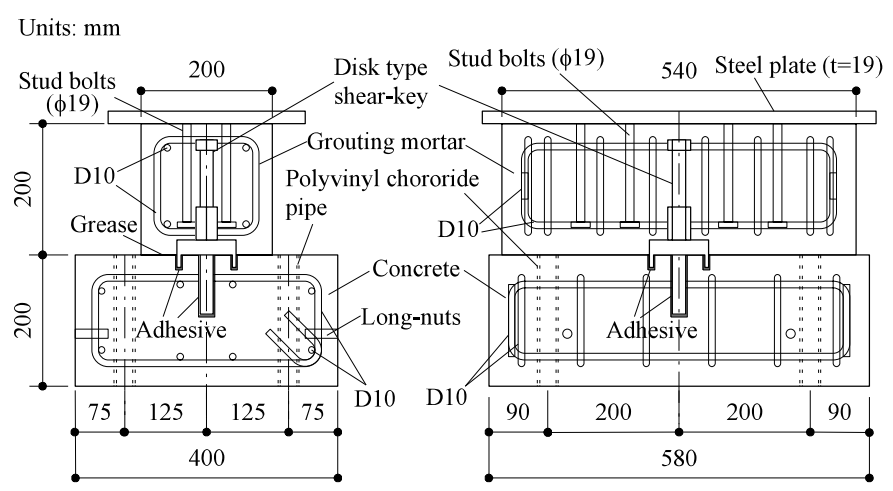

Sectional side view

Sectional front view

Fig.4 Details of specimens for shear loading test

Table 5 Material properties of concrete and grouting mortal

\begin{tabular}{cccc}
\hline & $\begin{array}{c}\sigma_{B} \\
\left(\mathrm{~N} / \mathrm{mm}^{2}\right)\end{array}$ & $\begin{array}{c}E_{c} \\
\left(\mathrm{kN} / \mathrm{mm}^{2}\right)\end{array}$ & $\begin{array}{c}\sigma_{t} \\
\left(\mathrm{~N} / \mathrm{mm}^{2}\right)\end{array}$ \\
\hline Grouting mortal & 67.9 & 21.9 & 3.2 \\
\hline Cement-based adhesive & 53.2 & 18.5 & 3.0 \\
\hline$\sigma_{B}:$ compressive strength, $E_{c}:$ Y oung's modulus, $\sigma_{t}:$ splitting strength
\end{tabular}

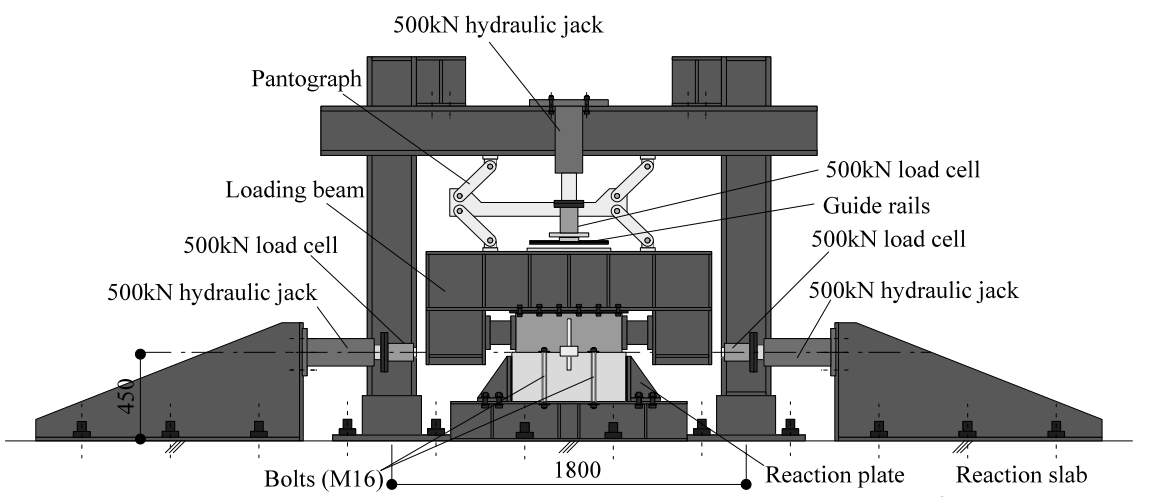

Fig.5 Loading equipment of shear loading test
余分な摩擦抵抗を少なくするためにグリスを塗布し， 2- $\phi 19$ のスタッ ドを溶接した鋼板と鉄筋籠を設置して，接合面と鋼板の間にグラウ 卜を圧入する。

\subsection{3 加力方法}

Fig.5 に本実験の加力装置を示す。加力装置には, せん断載荷用に 2 本, 軸力載荷用に 1 本の計 3 本の $500 \mathrm{kN}$ 油圧ジャッキを用いる。 軸力載荷用のジャッキの先端にロードセルを取り付け，これをガイ ドレールを介してコの字型加力ビームに固定する。またコの字型加 カビームを, 平行クランクを用いて加力フレームに固定することで, せん断載荷時に出来るだけ平行に変位するように配慮する。

試験体のコンクリート側は，コンクリートに埋め込んである塩ビ 管に高強度ボルトを通して, 加力フレームにナット締めし, せん断 載荷による回転に対する反力を得る。また, 加力フレームに反力用 の鋼製治具を取り付け，せん断荷重に対する反力とする。

\section{2 .4 計測方法}

Fig.6 に本実験の計測方法を示す。試験体の既存側コンクリートの 高さ中央の位置に, インサートを 2 箇所埋め込み, これに $50 \mathrm{~mm} \times$ $50 \mathrm{~mm}$ のアングルを固定する。ここにマグネットスタンドを用いて 高感度変位計を固定し，グラウトに設置したターゲットの相対水平 変位と相対鉛直変位を 2 箇所づつ計測し，それぞれの平均值をずれ 変形 $\delta$ と目開量 $\omega$ と寸る。せん断荷重は水平方向の油圧ジャッキに 取り付けたロードセルの值とする。載荷サイクルは正負交番の繰り 返し載荷とし, $\pm 0.25 \mathrm{~mm}, \pm 0.5 \mathrm{~mm}$ を 1 回, $\pm 1 \mathrm{~mm}, \pm 2 \mathrm{~mm}, \pm 3 \mathrm{~mm}$, $\pm 4 \mathrm{~mm}$ を 2 回, $\pm 6 \mathrm{~mm}$ を 1 回の強制変位を与える。

\section{3. 本解析の概要}

本論文では, 汎用有限要素解析ソフトDiana10.1を用いて, せん断 載荷実験を対象に解析する。以下に, 本解析の概要を述べる。

\section{1 要素分割}

Fig.7 に本解析モデルを示す。(a) に要素分割図を，(b)に界面要素 の位置と各界面要素のせん断応力 - 寸べり曲線（以下 $\tau-S$ 曲線と記 す）の概念図をそれぞれ示す。本研究では，まずは基礎的な解析を

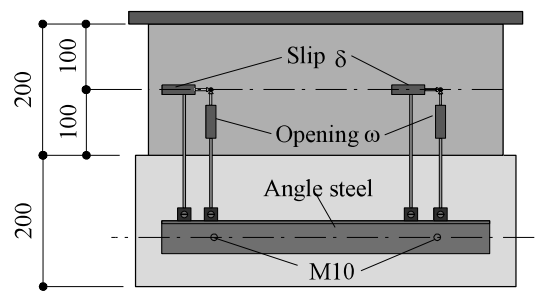

Fig.6 Details of mesurments

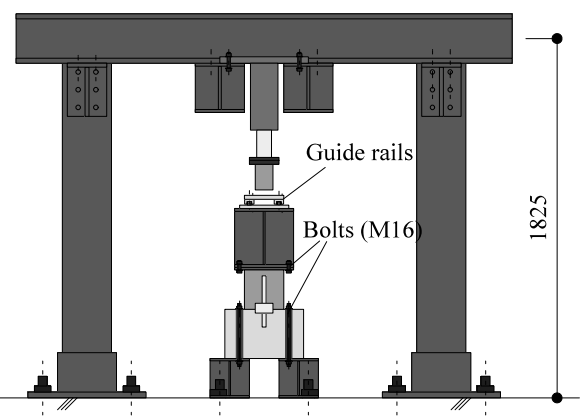




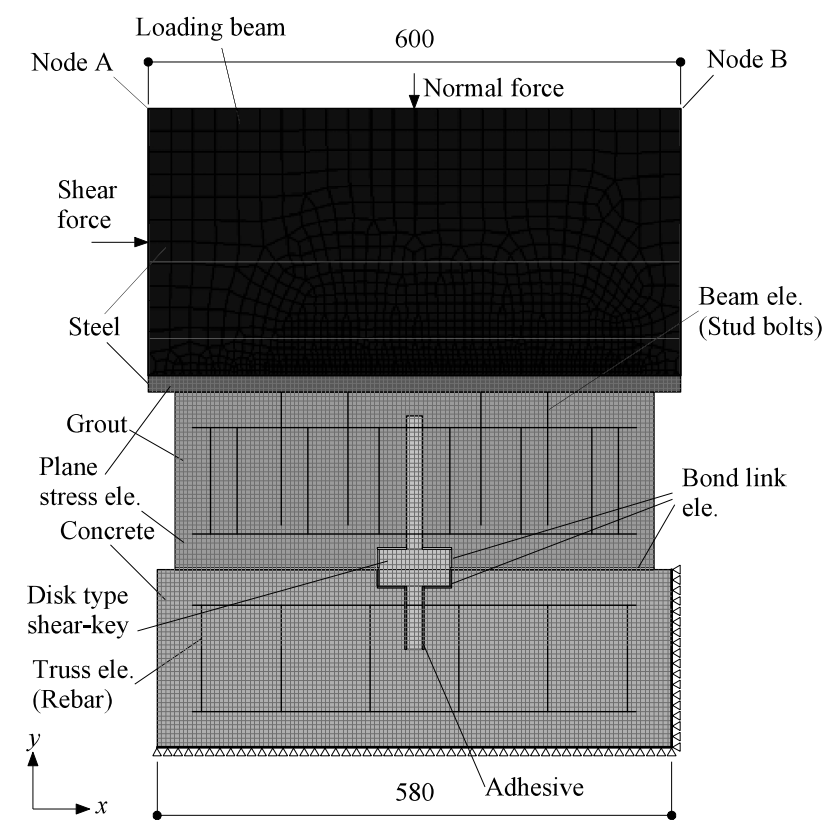

(a) M esh

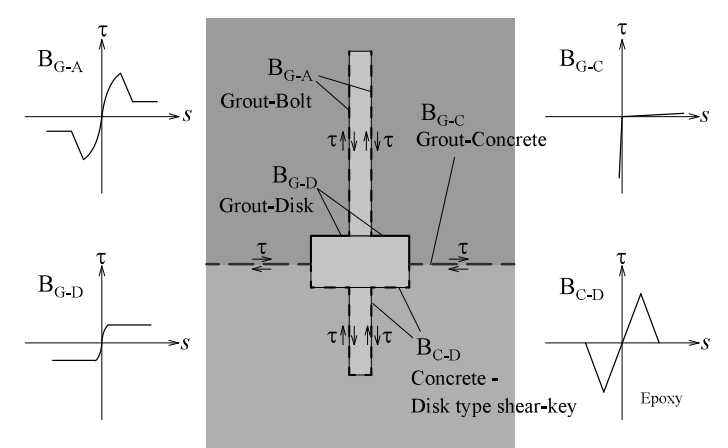

(b) J oint elements and images of $\tau-s$ curves in shear direction

Fig.7 Modelling for FEM analysis

行うため, 2 次元有限要素解析を実施する。本解析モデルのサイズは, せん断載荷用試験体と同一であり，試験体から加力フレームの一部 までをモデル化する。コンクリート, グラウト, 加力フレーム, 鋼 板およびディスク型シヤキーのディスクとアンカーボルトには，平 面応力要素を適用寸る。スタッドボルトは梁要素, 補強鉄筋はトラ ス要素とした埋め込み鉄筋要素を用いる。

ここで上記の通り，基本的にはせん断載荷用試験体の寸法と同一 になるように解析モデルの寸法を決定しているが，コンクリート要 素の厚さは, 試験体の $400 \mathrm{~mm}$ に対し, 本解析では $135 \mathrm{~mm}$ としている。 この理由は, 既往の論文 ${ }^{3)}$ で述べられているように, ディスク型シ ヤキーがせん断力を受けると，ディスク径 $R_{d}\left(R_{d}=90 \mathrm{~mm}\right)$ のおよそ 1.5 倍の範囲で既存コンクリートが大きく損傷するが，平面応力要素 を用いて解析すると, 奥行き方向の全断面が均一に応力を負担する ため, 要素厚さを $400 \mathrm{~mm}$ とすると, ディスク周囲に生じるコンクリー トのひずみに対し，応力が過小に算出される。そこで，実際の破壊 領域を考慮して，コンクリートの厚さを $1.5 R_{d}$ とした。この設定值の 妥当性については, 解析結果と実験結果の比較から検証する。

また本解析モデルでは，1) グラウトとディスク，2) グラウトと接 続ボルト，3) グラウトとコンクリート，4) コンクリートとディスク およびアンカーボルトの 4 つの界面要素（ボンドリンク要素）を適

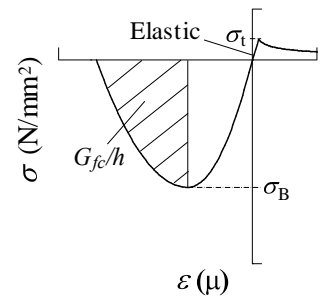

(a) Concrete

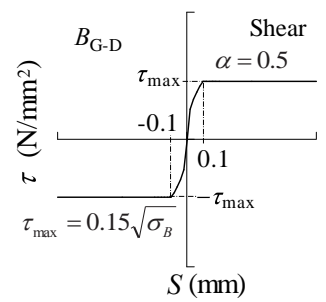

(c) B ond-slip between grouting mortal and disk in shear direction

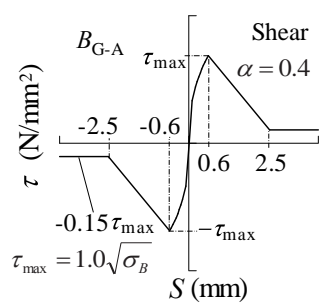

(e) B ond-slip between grouting mortal and bolt in shear direction

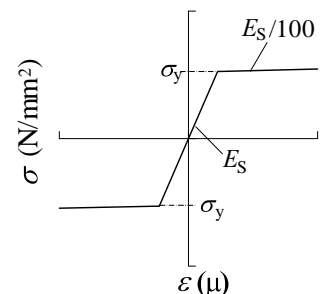

(b) Reinforced bar and stud

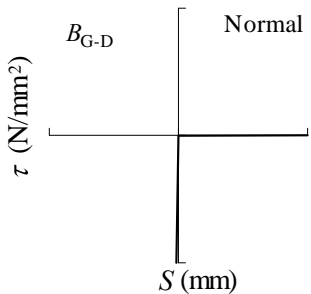

(d) B ond-slip between grouting mortal and disk in normal direction

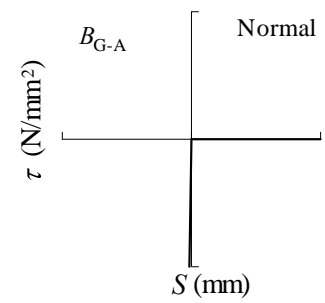

(f) B ond-slip between grouting mortal and bolt in normal direction
Fig. 8 Consutitutive laws

用し，それぞれ $B_{G-D}, B_{G-A}, B_{G-C}, B_{C-D}$ と呼称する。グラウトとアンカー ボルトについては，実験では接続ボルトの頂部に定着用のナットが 取り付いていることから，グラウトと接続ボルトの頂部の節点のみ 完全付着とする。また，ディスク型シヤキーで使用されるアンカー ボルトは，表面のほとんどがロ凸の無い滑らかな曲面であることか ら, $\mathrm{B}_{\mathrm{C}-\mathrm{D}}$ と同じ界面要素を適用寸る。同様に, ディスクの下面も, ディ スク側面と同じ表面を持つことから， $B_{C-D}$ を適用する。

\section{2 材料構成則}

Fig.8 に材料構成則を示す。コンクリートとグラウトの構成則は回 転ひび割れモデルを用いる。Fig.8(a) に示すように，等価一軸特性と して圧縮側は破壊エネルギー $G_{\mathrm{fc}}$ を考慮した放物線モデル，引張側に も引張破壊エネルギー $G_{\mathrm{ft}}$ を考慮した Hordijk Model l) を用いる。これ

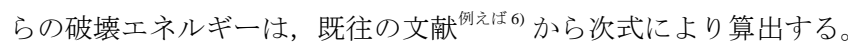

$$
\begin{aligned}
& G_{f c}=8.8 \sqrt{\sigma_{B}} \\
& G_{f t}=G_{f c} / 250
\end{aligned}
$$

Fig.8(b) より 鉄筋とスタッドはバイリニアモデルとする。加力フ レーム, 鋼板およびディスクはヤング率 $205 \mathrm{kN} / \mathrm{mm}^{2}$ の弾性体とする。 次に, 界面要素について記述する。 $B_{G-D}$ のせん断方向（界面要素 におけるせん断方向は, 要素の接線方向を, 垂直方向は法線方向を 意味する）には, CEB-FIP(1990) ${ }^{8)}$ モデルコードから鉄筋とコンクリー トの付着－すべりモデルを適用する。グラウトとディスク表面では, 高い付着強度を期待できないと考えられることから, 同モデルで使 用する各係数には, smooth bars の hot rolled barsにおけるAll other 
bond conditions の值を適用する。界面垂直方向はFig.8(d) に示寸よう， 引張に対しては十分に低い剛性, 圧縮に対しては逆に十分に高い剛 性を持つ弾性モデルとする。また， $B_{G-A}$ のせん断方向もCEB-FIP モ デルとし，接続ボルトにはねじ山があることから，この係数として unconfined concrete $の$ All other bond conditions を適用する。 $B_{G-A}$ の界 面垂直方向は $B_{G-D}$ と同一とする。

$B_{G . C}$ について，実験ではこの界面にグリスを塗布して付着を十分 小さくしていることから，せん断方向は十分低い剛性の弾性モデル とし, 垂直方向はFig.8(d) と同様とする。 $B_{C-D}$ についても, 界面垂直 方向はFig.8(d) と同様とするが，せん断方向には付着実験の結果から モデル化することとし，この詳細は次章で述べる。

\section{3 荷重条件および支持条件}

前掲のFig.7 に，加力点および支持点を示している。加力点は，本 実験と同様に，せん断力を加力ビームの上下の中央位置に，軸力 を左右中央の上縁に導入し, さらに鋼板が平行に移動するように, Fig.7 に示寸節点 B $9 y$ 方向の変位が節点 A と同一になるように拘束 する。支持方法についても本実験と類似するよう，コンクリートの 右側側面で $x$ 方向を固定し，コンクリート底辺で $y$ 方向を固定する。

\section{4. 付着実験およびせん断載荷実験の結果}

\section{1 付着実験の結果}

Fig.9(a) 〜 (i) に，付着実験の結果として各試験体の付着応力度一 滑り $(\tau-S)$ 曲線を示す。またTable6に実験結果の一覧を示す。こ の Table 6 の実験結果は, 各パラメータにおいて付着応力度が最大值 と最小值のものを除いた 3 体の試験体を対象としている。

以下の式 ${ }^{4)}$ を用いて, 付着応力度 $\tau$ を算出する。

$$
\tau=T /\left(\psi \times l_{e}\right)
$$

ここに， $\psi$ はアンカー筋軸部の周長（全ネジボルトについては公 称径を用いて算出する）， $l_{e}$ は有効埋め込夕深さ（実測值）である。

また，各種合成構造設計指針 ${ }^{4)}$ に基づいて，次式から基本付着強 度 $\tau_{\text {bavg }}$ を算出する。

$$
\tau_{\text {bavg }}=10 \sqrt{\sigma_{B} / 21}
$$

全ネジボルトを用いた試験体は，接着剤が大きく破壊しており， 丸鋼を用いた試験体は，一部の試験体で表層コンクリートの破壊を 伴いながら，基本的には接着剤とアンカーボルトの界面で破壊した。

Fig.9(a) (c) には全ネジボルトおよび無機系接着剂を用いた付着実 験の $\tau-S$ 曲線を示している。これらの図より，本実験で用いる無機 系接着剂の最大付着応力度は $\tau_{\text {bavg }}$ を上回わり, Table6 に示している ように, これらの試験体の安全率 $\alpha$ は 2 前後の值を示している。文 献 4) によれば，付着耐力の安全率はおよそ 2 となると記述されてい ることから，本実験で用いた無機系接着剂は，一般に使用される有 機系接着剂を用いた場合とほぼ同程度の付着耐力を発揮している。 したがって，付着特性の観点からは，本無機系接着剤は十分な付着 性能を有していると判断される。

次に丸鋼を用いたケースを観察する。Fig.9(d) (f) より，有機系接 着剂を用いると, 付着強度を超える場合もあれば, 下回る場合もあり， さらに標準偏差 $\sigma$ が大きく最大耐力は不安定になる。この理由とし て，丸鋼は異形鉄筋や全ネジボルトと異なり，接着剤による鋼材表 面の機械的抵抗を期待することができず，また注入型の接着剤を用
いていることから，接着剤とアンカー筋の間に僅かな空隙がある場 合には, 局所的に大きな応力が生じ, そこから破壊が進展するために, 極端に付着応力が小さくなるケースが生じる可能性あるのではない かと考えられる。

最後に, Fig.9(g) (i) に示寸無機系接着剤を適用した方は, 安全率 がおよそ0.2 0.3 とかなり小さく, 付着す心゙り特性も, 最大耐力後, アンカー筋が抜け出すような挙動を呈する。この要因としても，前 記の通り丸鋼には, アンカーボルトと接着剤の界面に，機械的な噛 み合い作用をほとんど期待できないことに起因するためと考えられ る。したがって，一般的な設計指針においても，丸鋼を用いた接着 系アンカーの使用は認められていない。

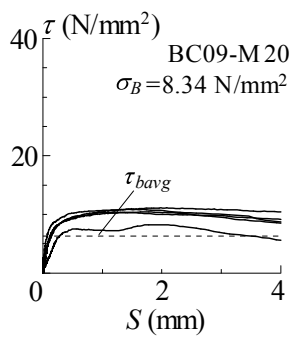

(a) B C 09-M 20

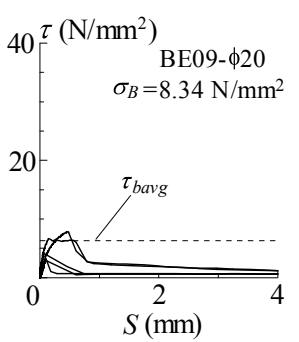

(d) BE09- $\$ 20$

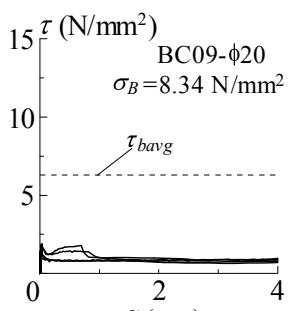

$S(\mathrm{~mm})$

(g) $B C 09-\phi 20$

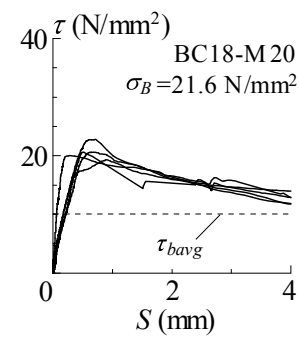

(b) BC 18-M 20

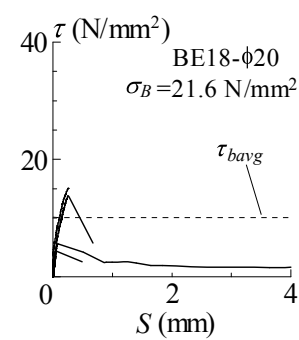

(e) $B E 18-\phi 20$

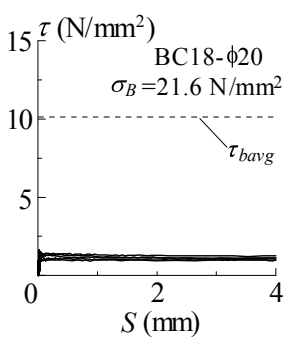

(h) BC $18-\phi 20$

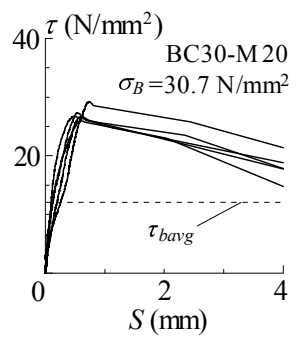

(c) BC 30-M 20

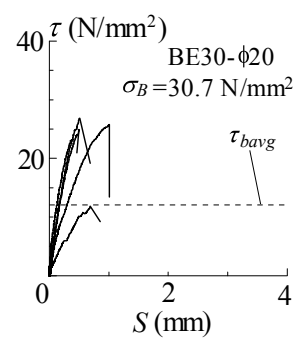

(f) $B E 30-\phi 20$

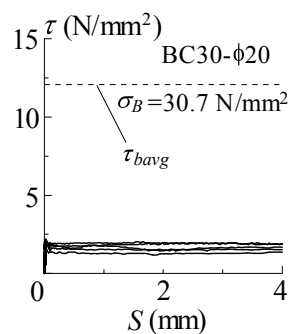

(i) $\mathrm{BC} 30-\phi 20$
Fig. $9 \tau-S$ relations of pull-out test

Table 6 Results of pull-out test results

\begin{tabular}{cccccc}
\hline $\begin{array}{c}\text { Spesimen } \\
\text { name }\end{array}$ & $\begin{array}{c}\tau_{\max } \\
\left(\mathrm{N} / \mathrm{mm}^{2}\right)\end{array}$ & $\begin{array}{c}s_{\max } \\
(\mathrm{mm})\end{array}$ & $\begin{array}{c}\tau_{\text {bavg }} \\
\left(\mathrm{N} / \mathrm{mm}^{2}\right)\end{array}$ & $\alpha$ & $\begin{array}{c}\sigma \\
\left(\mathrm{N} / \mathrm{mm}^{2}\right)\end{array}$ \\
\hline BC 09-M 20 & 12.10 & 1.42 & 6.30 & 1.92 & 0.25 \\
\hline BC18-M 20 & 23.43 & 0.49 & 10.13 & 2.31 & 0.39 \\
\hline BC30-M 20 & 26.96 & 0.53 & 12.08 & 2.23 & 0.37 \\
\hline BE 09- $\phi 20$ & 5.90 & 0.22 & 6.30 & 0.94 & 0.77 \\
\hline BE 18- $\phi 20$ & 10.20 & 0.12 & 10.13 & 1.01 & 4.98 \\
\hline BE 30- $\phi 20$ & 30.97 & 0.62 & 12.08 & 2.56 & 1.75 \\
\hline BC09- $\phi 20$ & 2.11 & 0.02 & 6.30 & 0.33 & 0.25 \\
\hline BC18- $\phi 20$ & 2.02 & 0.02 & 10.13 & 0.20 & 0.12 \\
\hline BC30- $\phi 20$ & 2.38 & 0.02 & 12.08 & 0.20 & 0.07 \\
\hline
\end{tabular}

$\tau_{\text {a }}$ : Maximum bond stress, $s_{\text {ax }}$ : Slip when maximum bond stress, $\alpha: \tau_{m} / \tau_{b}$ $\sigma:$ Standard deviation 


\section{2 せん断載荷実験の結果}

\subsection{1 目開き量の推移による軸応力の妥当性}

Fig.10(a) (c) に，各試験体の目開き量 $\omega^{-}$ずれ変形 $\delta$ 曲線を示す。 はじめに，既往のディスク型シヤキーのせん断載荷実験 ${ }^{3)}$ では，鉄 骨ブレースを既存 RC フレームに取り付けた架構実験の結果に基づ いて，下記の式によって目開きとずれ変形が制御されている。

$$
\omega_{t}=0.5 \times|\delta|
$$

$\omega_{\mathrm{t}}$ は目標目開き量である。本実験でもこの変位の条件を再現した かったが，本せん断載荷装置の鉛直方向の制御が手動の油圧ポンプ であることから，厳密に $\omega$ を制御することが困難であったため，軸 応力一定制御とした。せん断耐力の評価では， $\delta=2 \mathrm{~mm}$ までに発揮す る最大耐力を用いて，せん断耐力式が構築されており，この変位ま での鉛直変位の挙動が重要である。Fig.10には，式 (5) による $\omega_{\mathrm{t}}$ も 併記している。Fig.10(a) および (b) にそれぞれ示す $F_{c}=9 \mathrm{~N} / \mathrm{mm}^{2}$ およ び 18N/mm² の試験体について観察する。Fig.10(a) の両試験体の正側，

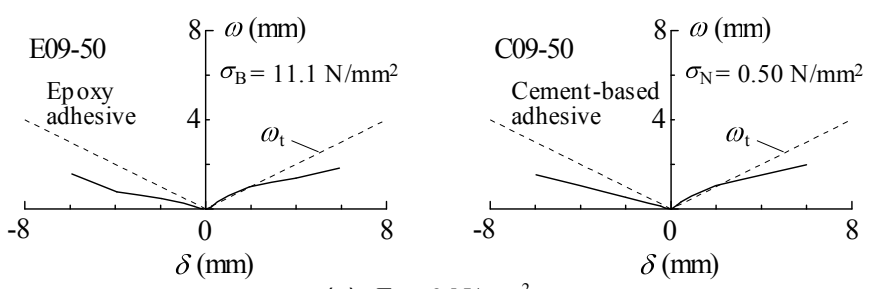

(a) $F_{C}=9 \mathrm{~N} / \mathrm{mm}^{2}$
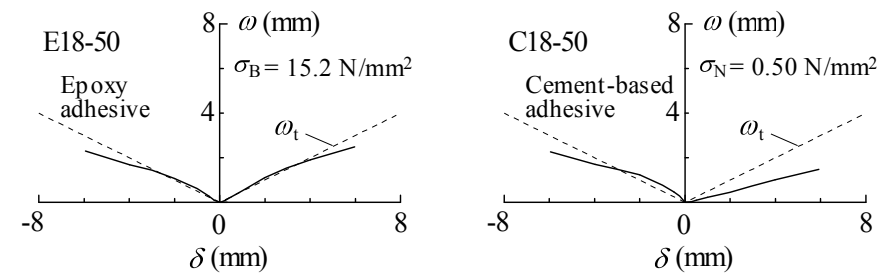

(b) $F_{C}=18 \mathrm{~N} / \mathrm{mm}^{2}$
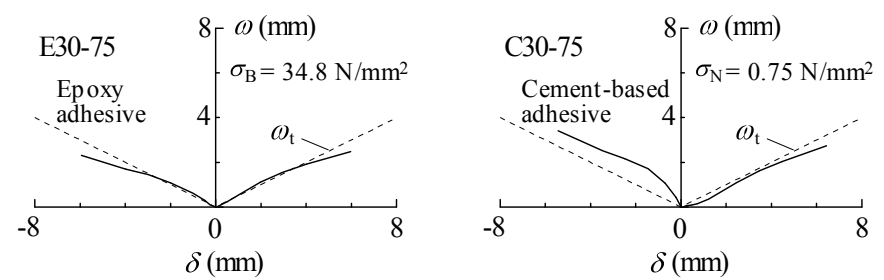

(c) $F_{C}=30 \mathrm{~N} / \mathrm{mm}^{2}$

Fig. $10 \omega-\delta_{\mathrm{S}}$ relations

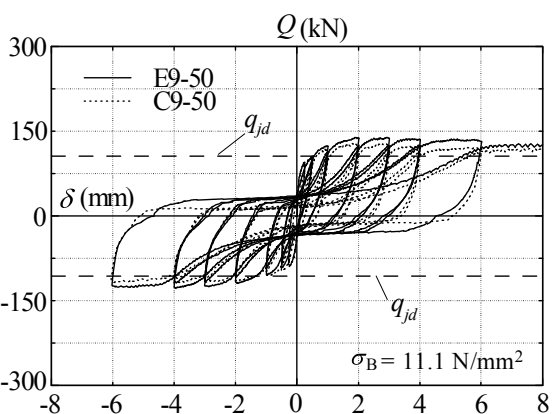

(a) $F_{C}=9 \mathrm{~N} / \mathrm{mm}^{2}$

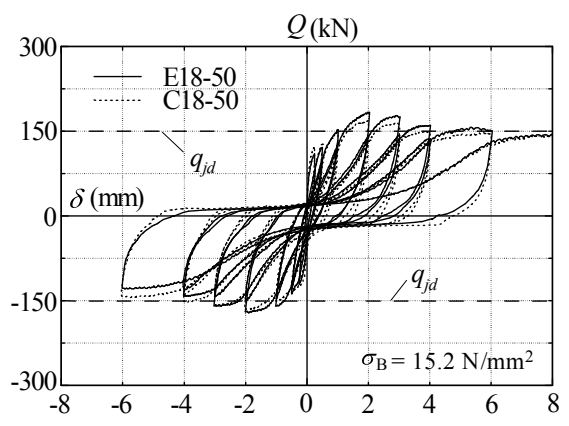

(b) $F_{C}=18 \mathrm{~N} / \mathrm{mm}^{2}$

Fig. $11 Q-\delta$ curves (b) のE18-50 の正負両側，およびC18-50の負側においては， $\delta=2 \mathrm{~mm}$ までは $\omega$ の推移が $\omega_{\mathrm{t}}$ にほぼ一致しているが， $\delta=2 \mathrm{~mm}$ 以降は $\omega$ が $\omega_{\mathrm{t}}$ を下回る。これはコンクリートの損傷の影響やディスクの傾き具合 など，僅かな実験状沉の変化で $\omega$ が左右され， $\omega$ と $\sigma_{N}$ が単純な関係 ではないことを示唆している。

続いて, $F_{c}=30$ とした試験体について検証する。本実験の予備実 験として, $F_{c}=30$ の試験体も $\sigma_{N}=0.5$ で載荷したが，その結果 $\omega$ が $\omega_{t}$ よりも大きくなり, せん断荷重も想定より小さくなった。そこで, $F_{c}=30$ の試験体については $\sigma_{\mathrm{N}}=0.75 \mathrm{~N} / \mathrm{mm}^{2}$ として載荷することとした。 Fig.10(c) より，C30-75 の負側で $\omega$ の挙動が $\omega_{\mathrm{t}}$ よりもやや大きめの推 移となるが，全体的には $\omega$ の挙動と $\omega_{\mathrm{t}}$ が一致している。

以上から，適切な軸応力の設定値，延いては接合部における変位 挙動の評価については, 課題が残されているが，本実験で設定した 軸応力とすることで，既往の部材実験とほぼ同条件で実験結果を評 価することができると判断される。

\section{2 .2 せん断荷重一ずれ変形関係}

Fig.11(a) (c) に，せん断載荷実験のせん断荷重 $Q-$ ずれ変形 $\delta$ 曲 線を示す。Table7 に実験結果の一覧を示す。

ディスク型シヤキーのせん断設計耐力 ${ }^{31,9)}$ は下式で表される。

$$
\begin{aligned}
q_{j d} & =0.8 \times 0.235 A_{B} \cdot K_{1} \cdot K_{2} \cdot K_{3} \cdot \sqrt{\sigma_{B} \times E_{C}} \\
A_{B} & =\pi \cdot R_{d} \cdot h_{d} / 4 \\
K_{1} & = \begin{cases}\mathrm{e} / \mathrm{e}_{e} & \left(e<e_{e}\right) \\
1.0 & \left(e_{e} \leq e\right)\end{cases} \\
K_{2} & = \begin{cases}L_{e} / 4.5 D_{a} & \left(3.0 D_{a} \leq L_{e}<4.5 D_{a}\right) \\
1.0 & \left(4.5 D_{a} \leq L_{e}\right)\end{cases} \\
K_{3} & = \begin{cases}1.0 \text { (普通コンクリート) } \\
0.9 \text { (軽量コンクリート) }\end{cases}
\end{aligned}
$$

\begin{tabular}{|c|c|c|c|c|c|}
\hline \multirow{2}{*}{$\begin{array}{c}\text { Spesimen } \\
\text { name }\end{array}$} & \multirow{2}{*}{$\begin{array}{r}q_{j d} \\
(\mathrm{kN})\end{array}$} & \multicolumn{2}{|c|}{$q_{\max }(\mathrm{kN})$} & \multicolumn{2}{|c|}{$\alpha=q_{\max } I q_{j d}$} \\
\hline & & $(+)$ & $(-)$ & $(+)$ & $(-)$ \\
\hline E09-50 & \multirow{2}{*}{106.7} & 139.3 & -128.1 & 1.31 & 1.20 \\
\hline C09-50 & & 128.9 & -117.7 & 1.21 & 1.10 \\
\hline E18-50 & \multirow{2}{*}{150.2} & 183.9 & -171.1 & 1.22 & 1.14 \\
\hline C18-50 & & 169.0 & -165.6 & 1.10 & 1.08 \\
\hline E30-75 & \multirow{2}{*}{266.2} & 296.6 & -268.8 & 1.11 & 1.01 \\
\hline C $30-75$ & & 268.2 & -263.9 & 1.01 & 0.99 \\
\hline
\end{tabular}

ここに $R_{d}$ はディスクの直径, $h_{d}$ はディスクの既存コンクリート への埋め込み深さ $\left(h_{d}=19 \mathrm{~mm}\right)$ である。 $K_{1}, K_{2}, K_{3}$ は補正係数であ

Table 7 Results of shear loading test

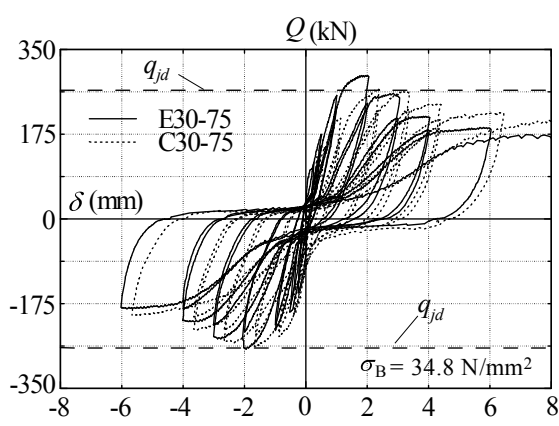

(c) $F_{C}=30 \mathrm{~N} / \mathrm{mm}^{2}$ 
り, $K_{1}$ の $2.0 R_{\mathrm{d}}$ である。本実験では，普通コンクリートに対し，へりあきが $200 \mathrm{~mm}$, 有効埋め込夕深さが $4.5 D_{\mathrm{a}}$ と, 一般的な条件で使用してい ることから全て 1 となる。

Fig.11 およびTable 7 より， $Q_{\text {max }}$ と式 (6) による設計耐力を比較す ると，C30-75の負側で安全率が 0.99 であるが，これを除くと有機 系接着剂を用いた試験体で $1.0 \sim 1.3$, 無機系接着剂を用いた試験 体で $1.0 \sim 1.2$ の範囲となっている。また全ての試験体において, $\delta=1 \sim 2 \mathrm{~mm}$ の範囲で設計荷重に達しており，有機系接着剤を用いた場

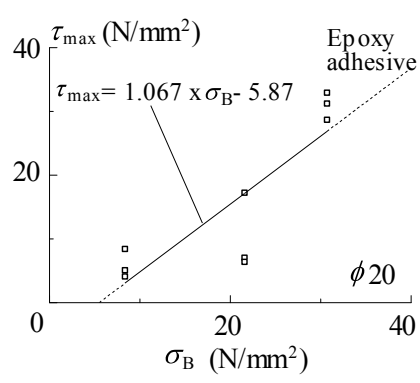

(a) Epoxy Adhesive

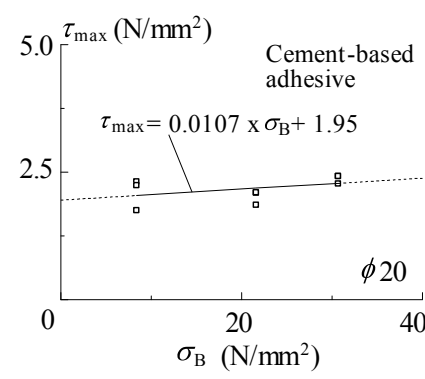

(b) Cement-based A dhesive
Fig.12 Bond - Slip modelling of adhesives

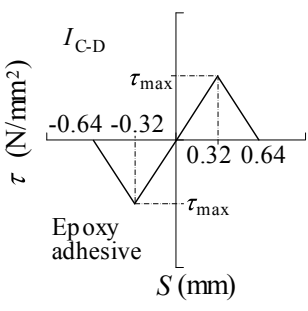

(a) Epoxy Adhesive

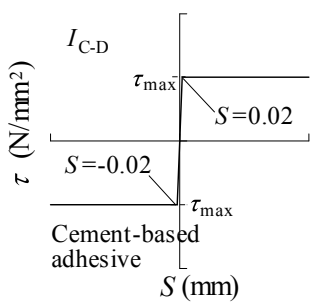

(b) Cement-based A dhesive
Fig.13 Bond - Slip modelling of adhesives

Table 8 Analysis case

\begin{tabular}{|c|c|c|c|c|c|}
\hline Case & $\begin{array}{c}\text { A nalytical } \\
\text { Case }\end{array}$ & $\begin{array}{c}F_{C} \\
\left(\mathrm{~N} / \mathrm{mm}^{2}\right)\end{array}$ & $\begin{array}{c}\text { Normal } \\
\text { stress }\left(\mathrm{N} / \mathrm{mm}^{2}\right)\end{array}$ & $\begin{array}{c}\tau_{\max } \\
\left(\mathrm{N} / \mathrm{mm}^{2}\right)\end{array}$ & $\begin{array}{c}\text { A nchorage } \\
\text { type }\end{array}$ \\
\hline \multirow{3}{*}{ Case-E } & A-E09 & 9 & 0.5 & 5.98 & \multirow{3}{*}{ Epoxy } \\
\hline & $A-E 18$ & 18 & 0.5 & 10.35 & \\
\hline & $A-E 30$ & 30 & 0.75 & 31.27 & \\
\hline \multirow{3}{*}{ Case-C } & A-C09 & 9 & 0.5 & 2.07 & \multirow{3}{*}{ Cement } \\
\hline & A-C 18 & 18 & 0.5 & 2.12 & \\
\hline & $A-C 30$ & 30 & 0.75 & 2.33 & \\
\hline \multirow{3}{*}{ Case-N } & A-N 09 & 9 & 0.5 & 0 & \multirow{3}{*}{ Non } \\
\hline & A-N 18 & 18 & 0.5 & 0 & \\
\hline & $A-N 30$ & 30 & 0.75 & 0 & \\
\hline
\end{tabular}

合 ${ }^{3)}$ と同様に，無機系接着剤を用いても十分に高い剛性を有してい ると判断される。なお，同じ $\sigma_{B}$ の試験体どうしを比較すると，有機 系接着剂を用いた試験体の方が，無機系接着剂を使用した場合より も, 正側の最大荷重 $Q_{\text {max }}$ が 1 割程度大きい。また, 前 4.2 .1 項で触れ た目開きの推移を改めて観察すると, 無機系接着剤を用いた試験体 の を呈している。一般に，目開きが大きいとせん断抵抗性能が低下寸 るように思われるが，一方でせん断力が大きくなると目開き易くな るとも考えられる。そのため本実験では，同一の $F_{\mathrm{c}}$ の試験体で軸応 力を同条件としていることから，ここで無機系接着剤の試験体のせ ん断耐力が低下した理由としては, 接着剤の付着特性の違いによる ものと考えるのが妥当である。

\section{2 次元有限要素解析の結果}

\section{1 付着一滑り $(\tau-S)$ 関係のモデル化}

Fig.12(a) および (b) に，付着実験における $\tau_{\max }{ }^{-} \sigma_{\mathrm{B}}$ 関係を示す。同 図には回帰直線も示している。

本解析を実施する目的の一つは，接着剤の違い，延いては付着特 性の違いがディスク型シヤキーのせん断抵抗性能に及ぼす影響を検 証することである。そのため, 接着剤のモデル化は非常に重要である。 ここでは, 前章で観察した, 丸鋼を用いた付着実験の結果に基づいて, 解析に用いる付着一すべりモデルを構築する。

Fig.13(a) および (b) に有機系接着剤と無機系接着剤の付着一すべり モデルをそれぞれ示す。前掲のFig.9 より有機系接着剤と無機系接着 剂に分けてモデル化する。Fig.12 に示す回帰式を使って最大付着強 度を算出する。また, 最大応力時の寸べり量は, 前傾の Table6 に掲 げている $S_{\max }$ より, 有機系接着剤では 3 種類のコンクリート強度の 平均值として $S=0.32 \mathrm{~mm}$, 無機系接着剂では $S=0.02 \mathrm{~mm}$ とする。

ピーク後の挙動も, 両接着剤で大きく異なることから, 有機系接 着剂では, 最大応力後, 応力が零になるように, 無機系接着剤では ピーク応力を維持するようにモデル化する。ただし, 非線形解析に おける収束性の問題から, 有機系接着剤では最大応力の割線剛性と 同じ勾配で $\tau=0$ になるように応力軟化させ，無機系接着剤について は，割線剛性の $1 / 100$ の剛性でひずみ硬化するモデルとした。

\section{2 せん断荷重一ずれ変形関係の実験值との比較}

Table 8 に解析ケースを示す。Fig.14の (a)， (b) および (c) に，それ ぞれ $F_{c}=9,18$ および $30 \mathrm{~N} / \mathrm{mm}^{2}$ の解析結果と実験結果の包絡曲線の 比較を示す。解析ケースとして, 本せん断実験を模擬した 6 ケース に加え, 接着剤の付着の影響を検証するために, 敢えて付着特性を アンボンドとしたケースを加えた, 計 9 ケースの解析を実施する。

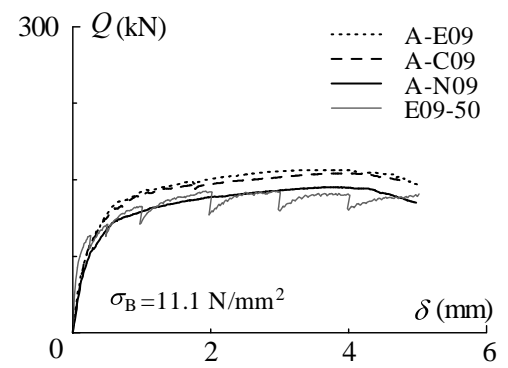

(a) $F_{C}=9 \mathrm{~N} / \mathrm{mm}^{2}$

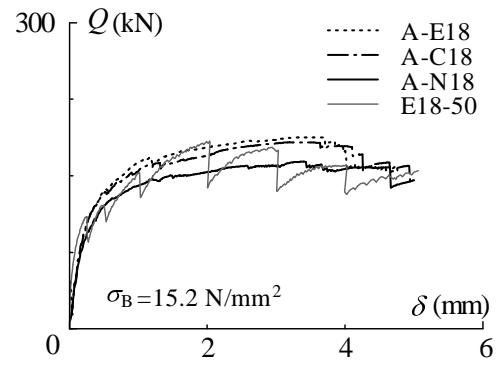

(b) $F_{C}=18 \mathrm{~N} / \mathrm{mm}^{2}$

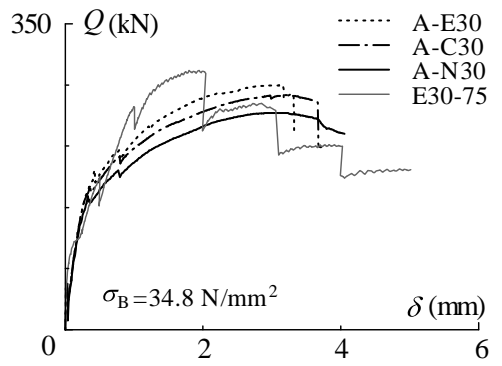

(c) $F_{C}=30 \mathrm{~N} / \mathrm{mm}^{2}$

Fig.14 Analytical resuls and envelope curves 


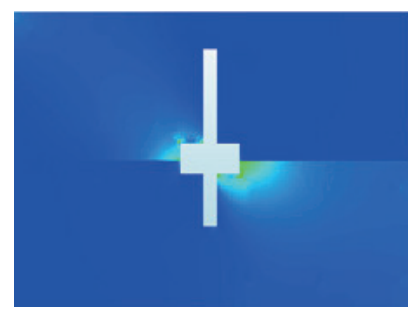

$\delta=0.1 \mathrm{~mm}$

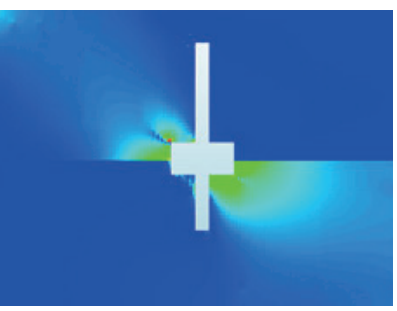

$\delta=0.25 \mathrm{~mm}$

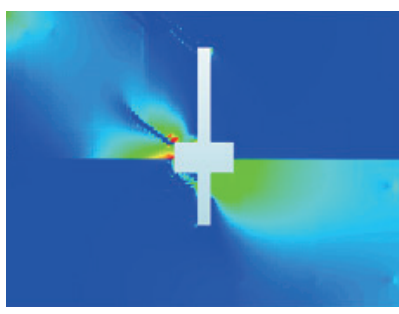

$\delta=0.5 \mathrm{~mm}$

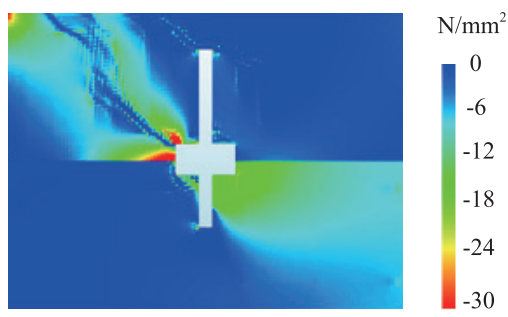

$\delta=1.0 \mathrm{~mm}$

Fig.15 Minimum principle stress of concrete and grout in A-E 09

付着特性を有機系接着剤，無機系接着剤，およびアンボンドとした 解析ケースを，それぞれC Case-E, Case-C, Case-N と呼称する。

Fig.14(a) から A-E09 とE09-50を比較すると，実験值であるE0950 よりも解析值の A-E09 の方が, Fig.14(C) ではA-E30よりも実験值 であるE30-75の方が，それぞれやや大きめの值を示している。これ に対し,Fig.14(b) では本解析（A-E18）により概ね実験結果（E18-50) を再現できている。本論文では解析的検討の初期段階であることか ら 2 次元有限要素解析を行っており, コンクリートの厚さとして平 面的な破壊状況からディスク径の 1.5 倍の数值を用いたが，この厚 さを用いることで，概ね良好に実験結果を再現できそうである。

次にFig.14の各解析ケースを比較する。Case-E と Case-N を比較 すると，(a) (c)の全てにおいて，ずれ変形の全領域でCase-N の方が せん断力が 1 割近く小さくなる。またCase-Cについては，(a) では Case-E より僅かに小さい挙動を示し, (b) と (c) については Case-E と Case-A の中間を推移する。つまり，いずれにしても接着剤の付着特 性が低い方が，せん断載荷実験と同様に， $Q-\delta$ 曲線のせん断力も小 さくなる傾向となった。したがって，接着剤の付着特性が，少なか らずディスク型シヤキーのせん断特性に影響を与えるものと推量さ れる。

\section{3 最小主応力分布および支圧抵抗領域}

Fig.15に $\delta=0.1 ~ 1.0 \mathrm{~mm}$ のコンクリートおよびグラウトの最小主応 力分布を, Fig.16にディスクの変位と支圧抵抗領域の関係を示す。 Fig.15の $\delta=0.1$ の最小主応力分布に着目すると, せん断載荷方向の ディスク側面とディスク底面側に, 応力が集中して生じていること が理解できる。すなわち，Fig.16に示寸ように，ディスク型シヤキー にせん断力が作用すると, アンカーボルトが抜け出しながら，ディ スクが傾き, その結果, ディスク右側の側面のせん断載荷方向から, 下面方向に圧縮（支圧）応力が生じ, さらにこのディスク下面方向 への圧縮応力の増大に伴って, ディスクと既存側コンクリートの間 に摩擦応力が生じることで, 増設側から既存側にせん断力が伝達す ると推測される。

そこで, この応力の様相をより詳細に考察するために, アンカー ボルトの左下隅の節点 (Fig.16の Node-a) の鉛直変位 ${ }_{\mathrm{A}} \delta_{\mathrm{Y}}$ とディスク の右下隅の節点 (Fig.16の Node-d) の鉛直変位 ${ }^{\circ} \delta_{Y}$ の推移を，それぞ れ Fig.17 およびFig.18に示す。本解析ではディスクを弾性体として いるため, ディスクが変形することはほとんど無い。この Fig.17 と Fig.18のグラフで, 縦軸が正の值は, 上方向に変位したことを意味 する。また, 設計せん断力に達する $\delta=2 \mathrm{~mm}$ までの挙動を表示する。

Fig.17より， $F_{C}$ に関わらず全体的に Case-N が最も鋁直変位が大き い。またCase-E とC Case-C を比べると, Fig.17(a) および (b)では, 両 者とも同様の推移を示す。Fig.17(c) では $\delta=1 \mathrm{~mm}$ までは，両者とも同

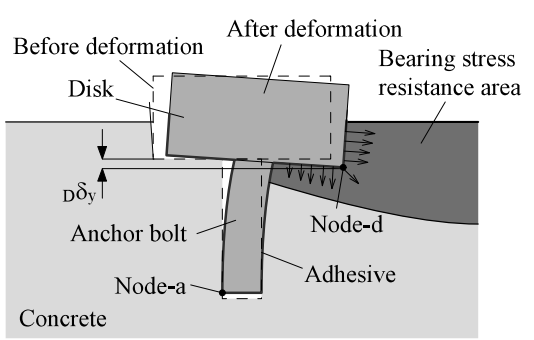

Fig.16 Reration between bearing resistance and displacement of Disk

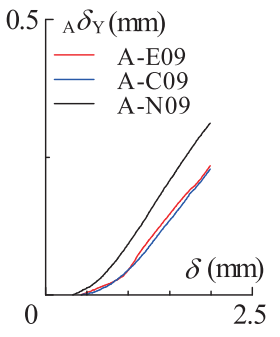

(a) $F_{C}=9 \mathrm{~N} / \mathrm{mm}^{2}$

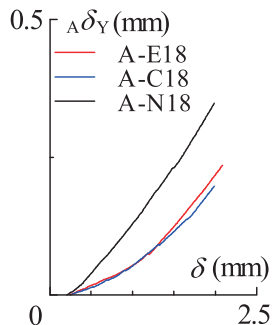

(b) $F_{C}=18 \mathrm{~N} / \mathrm{mm}^{2}$

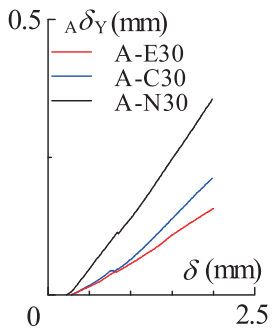

(c) $F_{C}=30 \mathrm{~N} / \mathrm{mm}^{2}$
Fig.17 Vertical displacemento of Node-a

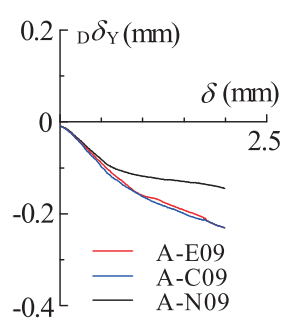

(a) $F_{C}=9 \mathrm{~N} / \mathrm{mm}^{2}$

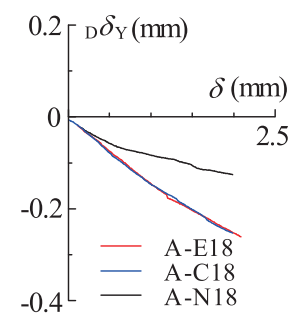

(b) $F_{C}=18 \mathrm{~N} / \mathrm{mm}^{2}$

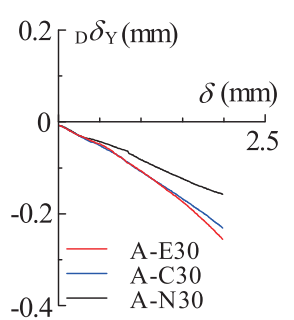

(c) $F_{C}=30 \mathrm{~N} / \mathrm{mm}^{2}$
Fig.18 Vertical displacement of Node-d

様の挙動となるが，これ以降はCase-E の鉛直変位が小さくなる。続 いてFig.18より，ディスクの右下端の鉛直変位に着目すると，大小 の傾向はFig.17 と同様である。さらに, これらの関係はFig.14に示 したQ- $\delta$ 曲線の大小関係の傾向ともほぼ一致する。前掲の Fig.15に 示したように, ディスクの右下側の最小主応力が， $\delta$ の進展とともに 大きくなっていることから, アンカーボルトの付着性能が高くなる と, アンカーボルトの抜け出しが小さくなり, ディスクが既存側コ ンクリートに接する面積が大きくなる。これにより, ディスク側面 での支圧面積や, ディスク下方向への圧縮ひずみも大きくなるなど, 様々な現象が複合することで, 結果的にせん断力が大きくなったと 推察される。

以上に述べた本論文全体の考察を総括すると, せん断載荷実験に おける Q- $\delta$ 曲線の特性や, 例外はあるが最大耐力が設計せん断力を 
ほぼ上回ったことから，無機系接着剤をディスク型シヤキーに適用 しても, 大きな問題はないと判断される。また接着剤の付着特性が, せん断抵抗性能に及ぼす影響について，有限要素解析により定性的 な傾向を把握することができた。しかしながら，この定量的な評価 までには至らず，さらに有機系接着剤と無機系接着剤の違いによる, せん断抵抗性能の差異を, 解析で正確に再現することは出来なかっ た。今後, 解析精度の向上や, さらには付着特性の違いを考慮した 力学モデルおよび設計法を構築していきたいと考えている。

\section{6. 結論}

本論文では，無機系接着剤をディスク型シヤキーに適用できるか 検証することを主たる目的として，接着剤の付着実験，ディスク型 シヤキーのせん断載荷実験および 2 次元有限要素解析を実施した。 以下に，本論文で得られた知見を列記する。

1) 本論文で用いたエポキシ系の有機接着剂を丸鋼に適用して付着実 験を行った結果, 最大強度は付着強度 $\tau_{\text {bavg }}$ に対し安全率が 1 を超 える場合も，超えない場合もあり，どの $F_{\mathrm{c}}$ のケースでも標準偏差 が大きく不安定であった。

2) 本論文で用いたセメント系の無機系接着剂を，全ネジボルトに適 用して付着実験を実施した結果，有機系接着剤と大きな違いは見 られなかった。しかしながら，丸鋼を用いた場合は付着強度 $\tau_{\text {bavg }}$ に対する安全率が 0.2 0.3 と非常に小さく, また最大荷重後に, 丸鋼が滑り出し，荷重一定のまま引抜変位が進展した。

3) 主成分が大きく異なる有機系と無機系の 2 種類の接着剤を用いて, 接合部を模擬したせん断載荷実験を行った結果，無機系接着剤を 用いた場合の方が， 1 割程度せん断耐力が低下したが，設計せん 断耐力式に対する安全率は, $F_{\mathrm{C}}=30 \mathrm{~N} / \mathrm{mm}^{2}$ のケースの負側で 0.99 となった以外は 1 を超えた。

4) 付着実験で得られた接着剤の付着すべり特性をモデル化し，せん 断載荷実験を再現する 2 次元有限要素解析を実施した。平面応力 要素を用いることから, 要素厚さを支圧破壊領域に準じて $1.5 R_{d}^{3 !}$ とすることで，実験結果を概ね再現できることが分かった。ただ し, 有機系接着剂と無機系接着剂の付着特性の違いが，せん断抵 抗性能の違いに与える影響を正確に，解析で再現することは出来 なかった。

5) 本解析の結果, 付着特性をアンボンドとした解析ケースでは, 接 着剂の付着特性を考慮した場合に比べ，せん断力が小さくなった。 この要因として, 付着強度が小さくなると, アンカーボルトの抜 け出しが大きくなり，これに伴ってディスク側面と底面での支圧 抵抗や摩擦抵抗が小さくなったためと推測される。

6) 本論文で用いた無機系接着剤をディスク型シヤキーに適用して, せん断載荷実験および 2 次元有限要素解析を行った結果, 現行の 設計せん断耐力を超え，最大耐力時のずれも有機系接着剤を用い た場合と大きな差異はなく, 十分に適用可能であると判断できる。 無機系接着剤を用いた本せん断載荷実験の結果では，設計耐力に 対する安全率がやや 1 を超える程度であったことから, 実際の設計 で用いる際には，十分余裕を持って安全側に設計する必要がある。 また本検討結果は，無機系接着剤をディスク型シヤキーに適用した 場合に適用できるものであり，一般的なあと施工アンカーに適用す る場合には, 改めて検証する必要がある。

\section{謝辞}

本研究に際し, 室蘭工業大学平成 28 年度卒論生・岩崎稜君, サン コーテクノ・八木沢康衛氏，佐藤貴志氏には，多大なるご協力を賜 りました。ここに，深い感謝の意を表します。

\section{参考文献}

1) The Japan Building Disaster Prevention Association: Seismic evaluation and retrofit, 2001.9 (in Japanese)

日本建築防災協会 : 2001 年改定版 既存鉄筋コンクリート造建築物の耐震 改修設計指針・同解説, 2001.9

2) Takase, Y., Sato, T., Imai, K., Onaka, A., Abe, T., Ikeda T. and Kubota M. Basic investigation of new join element having high shear strength and stiffness for earthquake retrofitting of concrete structures - Study on shearkey consisted of steel disk and anchor bolt for earthquake retrofitting-, Journal of Structural Construction Engineering(Transactions of AIJ), Vol. 77, No.681, pp.1727-1736, 2012.11 (in Japanese) 高瀬裕也ら他 6 名 : コンクリート系構造物の耐震補強に用いる高いせん断耐 力と剛性を持つ新たな接合要素のせん断抵抗性能の基礎的検証 - 鋼製ディス クとアンカーボルトを併用した耐震補強用シヤキーに関する研究 -, 日本建 築学会構造系論文集, Vol.77, No.681, pp.1727 1736, 2012.11

3) Takase, Y., Abe, T., Itadani, H., Sato, T., Onaka, A., Kubota M. and Ikeda T. : Estimation method of horizontal capacity of joint fracture for retrofitted frame using disk shear-key - Study on shear-key consisted of steel disk and anchor bolt for earthquake retrofitting-, Journal of Structural Construction Engineering(Transactions of AIJ), Vol. 79, No.698, pp.507-515, 2014.4 (in Japanese)

高瀬裕也ら他 6 名 :ディスク型シヤキーを用いた内付け補強架構の接合部 破壊時の保有水平耐力の評価手法 - 鋼製ディスクとアンカーボルトを併用し た耐震補強用シヤキーに関する研究 -, 日本建築学会構造系論文集, Vol.79, No.698, pp.507 515, 2014.4

4) Architectural Institute of Japan: Design recommendations for composite constructions, 2010 (in Japanese) 日本建築学会 : 各種合成構造設計指針・同解説, 2010

5) Ando, S., Nakano, K., Watanabe, K., Nakagawa, H., Tanuma, T., Yahata, S., Sakakibara, H. and Akasaka, T: Average bond strength of post-installed rapid hardening cement bonded anchor, Summaries of Technical Papers of Annual meeting, Architectural Institute of Japan, Struct. IV, pp.201-202, 2012.9 (in Japanese)

安藤重裕ら他 7 名: 超速硬セメント系注入式あと施工アンカーの付着特性, 日本建築学会大会学術講演梗概集, 構造 IV, pp.201 202, 2012.9

6) Architectural Institute of Japan: Analytical models of concrete structures and their applications for design, 2008.3 (in Japanese)

日本建築学会：コンクリート系構造の部材解析モデルと設計への応用, 2008.3

7) Hordijk, D., A.: Tensile and tensile fatigue behaviour of concrete; Expriments, modelling and analysis, Heron, Vol. 37, No.1, pp.35-39, 1992 8) CEB: CEB-FIP MODEL CODE 1990, pp.83, 1990

9) Sato, T., Yagisawa, Y., Ikeda T., Imai, K., Takase, Y., Onaka, A., Abe, T., Itadani, H. and Kubota, M.: Development of joint member using steel disk and anchor bolt for earthquake retrofit -Pt.6 Application of light-weight concrete-, Summaries of Technical Papers of Annual meeting, Architectural Institute of Japan, Struct. IV, pp.205 206, 2012.9 (in Japanese) 佐藤貴志ら他 8 名 : 鋼製ディスクとアンカーボルトを併用した耐震改修用接 合部材の開発 その 6 軽量コンクリートへの適用, 日本建築学会大会学術講 演梗概集, 構造 IV, pp.205 206, 2012.9 


\title{
ADAPTABILITY OF CEMENT-BASED ADHESIVE TO DISK TYPE SHEAR-KEY
}

\author{
Takahide $A B E^{* 1}$, Yuya TAKASE ${ }^{* 2}$, Sigehiro ANDO*3, \\ Keita SAKAMOTO ${ }^{* 4}$, Tsutomu TAMURA ${ }^{* 5}$ and Takayuki KANEYOSHI ${ }^{* 6}$ \\ ${ }^{* 1}$ Chief, Seismic solution department, TOBISHIMA Corporation \\ *2 Assoc. Prof., College of Environmental Technology, Muroran Institute of Technology, Ph.D. \\ ${ }^{*}$ Manager, Concrete research laboratory, SUMITOMO OSAKA CEMENT Co., Ltd., Dr.Eng. \\ ${ }^{* 4}$ Chief, Seismic solution department, TOBISHIMA Corporation, M.Eng. \\ ${ }^{* 5}$ Subsection chief, Concrete research laboratory, SUMITOMO OSAKA CEMENT Co., Ltd. \\ ${ }^{*}$ Manager, Cement-related products division, SUMITOMO OSAKA CEMENT Co., Ltd.
}

\begin{abstract}
Seismic retrofitting has recently become crucial for buildings designed under old seismic codes. Post-installed anchors or disk-type shear keys are generally applied to joints of seismic retrofitting structures, which are further anchored to the existing members by applying epoxy adhesives. Although epoxy adhesives have been studied extensively, few studies exist on cement-based adhesives. Therefore, we conducted a pull-out test, a shear loading test, and a two-dimensional (2D) FEM analysis to investigate the adaptability of cementbased adhesives to disk-type shear keys.

In Chapter 2, the test plans for the pull-out and shear loading tests are detailed. Nine specimens were prepared for each test. The parameters of the pull-out test include the concrete compressive strength $\sigma_{B}\left(10-30 \mathrm{~N} / \mathrm{mm}^{2}\right)$, adhesive type (epoxy or cement-based adhesive), and anchor bolt type (fully threaded bolt or round steel bar). The parameters of the shear loading test are $\sigma_{\mathrm{B}}$ and adhesive type.

In Chapter 3, the FEM analysis is outlined. In this analysis, the concrete and the steel are considered as a plane stress element, the stud bolts as a beam element, and reinforced bars as a truss element. A concrete thickness of $135 \mathrm{~mm}\left(=1.5 R_{\mathrm{d}}\right.$, where $R_{\mathrm{d}}$ is the diameter of the steel disk) is considered as the damage area of the disk-type shear key. The analytical parameters are the concrete compressive strength $\sigma_{B}$ and the adhesive type. In adhesive type, the case of "unbonded" is also added as a parameter.

Chapter 4 describes the test results. A ccording to the results of the pull-out test, use of the cement-based adhesive with a fully threaded bar resulted in the same maximum bond stress as with epoxy adhesives. However, the maximum bond strength was $0.2-0.3$ times the bond strength in case of a round steel bar. The shear loading test results indicated that the shear forces of the cement-based adhesive were slightly smaller than those when the epoxy adhesive was used.

Chapter 5 describes the analytical results. First, the bond-slip behavior of adhesives was modeled from the results of the pull-out test. The analytical outcomes of the nine cases were calculated. The $Q-\delta$ curves obtained from the analysis and the experiment were similar. Moreover, the shear forces in the unbonded case were smaller than those in case of epoxy and cement-based adhesives because the bearing resistance area was smaller because of the pulling out of the anchor bolt.

Chapter 6 presents the conclusions of the study, which are summarized as follows:

1) The results of the pull-out test using an epoxy adhesive and a round steel bar show a safety ratio exceeding 1.0, but with a higher standard deviation.

2) The pull-out test results indicate that the combination of a cement-based adhesive and a fully threaded bar resulted in the maximum bond stress same as that in case the when an epoxy adhesive was used. However, a round steel bar exhibited the maximum bond strength that was 0.2-0.3 times the bond strength.

3) The shear loading test results show that the maximum shear force of the specimens using cement-based adhesives was approximately $10 \%$ smaller than that of the specimens using epoxy adhesives. These maximum shear forces were, however, higher than the calculated shear strength in most specimens.

4) The shear behavior could be reproduced by the $2 \mathrm{D} \mathrm{FEM}$ analysis by setting the concrete element thickness to $1.5 R_{\mathrm{d}}$.

5) The bond strength and the vertical displacement of the anchor bolt obtained by the analysis were smaller and larger, respectively, compared with the experimental results.

6) From these investigations, it was concluded that cement-based adhesives can be applied to disk type shear keys.
\end{abstract}

